\title{
Endosülfan ve C Vitamini Uygulamalarının Erkek Yeni Zellanda Tavşanları Ü̉zerindeki Etkisi
}

\author{
Özlem YILDIZ GÜLAY1', Tülay BÜYÜKOĞLU², Fatma Şefika HATİPOĞLU1*, \\ Mehmet Şükrü GÜLAY ${ }^{1}$
}

${ }^{1}$ Mehmet Akif Ersoy Üniversitesi, Veteriner Fakültesi, Fisyoloji Anabilim Dah
${ }^{2}$ Mehmet Akif Ersoy Üniversitesi, Veteriner Fakültesi, Biyokimya Anabilim Dalı

*Corresponding author e-mail: offermann.sefika@googlemail.com

\begin{abstract}
ÖZ
Çalışmamızda endosülfan uygulaması yapılan erkek Yeni Zellanda tavşanlarında C vitamini (VitC) ilavesinin bazı kan ve biyokimyasal parametreler ile oksidan-antioksidan denge üzerine düzeltici etkisinin araştırlması amaçlanmıştır. Bu amaçla, yaşları 6 ile 8 ay arasında değişen 24 tavşan, her grupta 6 tavşan olacak şekilde, rastgele 4 çalışma grubuna ayrıldı. Kontrol grubundaki tavşanlara (TRT-I) mısır yağı verildi. İkinci grupta bulunan tavşanlara (TRT-II) günlük $1 \mathrm{mg} / \mathrm{kg}$ endosülfan mısır yağında eritilerek verildi. Üçüncü gruptaki tavşanlara $20 \mathrm{mg} / \mathrm{kg}$ dozunda VitC gün aşırı olarak uygulandı (TRT-III). Son gruptaki tavşanlara (TRT-IV) aynı oranlarda endosülfan ve VitC verildi. Oral yolla yapılan bu uygulamalar 6 hafta boyunca devam etti. Çallşmamızda toplam eritrosit ve trombosit, hemoglobin, hematokrit, ve lökosit değerleri yönünden gruplar arasında fark gözlenmezken, toplam lökosit sayılarında anlamlı bir fark bulundu. Ayrıca serum glukoz, alanin aminotransferaz (ALT), malondialdehit (MDA), glukoz 6 fosfat dehidrojenaz (G6PD), glutatyon peroksidaz (GPx) ve eritrosit katalaz (CAT) aktivitelerinde de farkllık tespit edilmedi. TRT-III grubunda serum VitC seviyesi yükselirken, TRTII grubunda serum alkalen fosfataz (ALP) ve aspartat aminotransferaz (AST) seviyeleri arttı. Bununla birlikte VitC uygulamasının TRT-IV grubundaki tavşanlarda ALP ve AST seviyelerini TRT-II grubuna göre azalttığı gözlendi. Elde edilen bulgulara göre, VitC uygulamasının endosülfanın bazı zararlı etkilerine karşı erkek Yeni Zellanda tavşanlarında koruyucu olabileceği sonucuna varıldı.
\end{abstract}

Anahtar kelimeler: kan parametreleri, biyokimyasal parametreler, oksidan-antioksidan denge, endosülfan toksikasyonu, insektisit kullanımı, Vitamin C

\section{Effects of Vitamin C on Male New Zealand White Rabbits Exposed to Endosulfan}

\begin{abstract}
The present study evaluated the protective effect of oral Vitamin C (VitC) against changes in hematological and biochemical parameters, and oxidant-antioxidant status in male New Zealand White rabbits treated with endosulfan. Total of 24 rabbits ( 6 to 8 years old) were randomly divided into 4 treatment groups $(n=6)$. Rabbits in the control group (TRT-I) received corn oil for 6 weeks. Rabbits in the second group (TRT-II) received endosulfan (1 $\mathrm{mg} / \mathrm{kg}$ bw per day) in corn oil. Rabbits in the third group (TRT-III) received corn oil daily and VitC (20 mg/ kg bw) every other day for 6 weeks. Rabbits in the last group (TRT-IV) received the same amounts of endosulfan and VitC. All treatments were administered by oral route. Although total erythrocyte, trombocyte, hemoglobin and percent hematocrit, lymphocyte, granulocyte and monocyte did not differ among the treatment groups, total leukocyte numbers differed due to treatment. The serum glucose, alanine aminotransferase (ALT), malondialdehyde (MDA), glucose 6 phosphate dehydrogenase (G6PD), glutathion peroxidase (GPx), and erythrocyte catalase (CAT) in treatment groups were similar. However, serum VitC levels were elevated for rabbits in TRT-II group. In addition, serum alkaline phosphatase (ALP) and aspartate aminotransferase (AST) levels increased in the TRT-II group, whereas VitC application decreased ALP and AST levels in the TRT-IV group when compared to the TRT-II group. Thus, results suggested beneficial influences of VitC in neutralizing some harmful effects of endosulfan in male New Zealand White rabbits.

Keywords: blood parameters, biochemical parameters, oxidant-antioxidant status, endosulfan toxication, insecticide use, Vitamin C




\section{GİRIŞ}

Endosülfan tarım ürünleri yetiştiriciliğinde bitkileri zararlılardan korumak için dünya çapında ve Türkiye'de de sıkça kullanılan organik klorlu bir insektisittir. Sebze ve meyve zararlılarını kontrol altına almakta kullanılan endosülfan $(6,7,8,9,10,10$ hexachloro - 1,5,5a,6,9,9a - hexahydro - 6,9 methano -2,4,3- benzodioxathiepin - 3 - oxide) geniş spektrumlu, cyclodiene grubuna ait organoklorlu pestisitlerden birisidir (Zhang ve ark, 2017). Zirai mücadele ilac1 olarak bitkilerdeki insektisitlere karşı oldukça etkili bir ilaç olmasına rağmen, bitkilerde ve sularda yüksek konsantrasyonlarda birikebilmekte (Menezes ve ark, 2017; Simonich ve Hites 1995; Xu ve ark., 2016), insan ve hayvanlarda akut toksisiteye de sebep olabilmektedir (Sharma ve ark, 2017). Endosülfanın LD50 dozu uygulama yoluna, türe, içinde bulunduğu maddenin türüne ve hayvanın cinsiyetine göre değișir. Oral LD50 dozu ratlar için $9.6-160 \mathrm{mg} / \mathrm{kg}$, fareler için $13.5-35 \mathrm{mg} / \mathrm{kg}$ arasinda bulunmuştur (Bremer ve Leist 1998).

Akut endosülfan intoksikasyonunun insanlarda metabolik asidoza, yüksek anyonik duruma, hiperglisemiye ve trombositlerde azalmaya neden olduğu anlaşılmıştır (Blanco ve ark. 1992). Endosülfanın, eritrosit sayısını azalttığı, eritrosit glutatyon redüktaz (GR) düzeyi ve aktivitesini, kan hemoglobin konsantrasyonu ve MCV'ü düşürdüğü rapor edilmiştir (Naqvi ve Vaishnavi 1993). Yine aynı çalışmada glukoz 6-fosfataz aktivitesi ve kan glukoz düzeyinde artma, plazma $\mathrm{Ca}$ düzeyinde ve $\mathrm{Na}, \mathrm{K}, \mathrm{Mg}$ ATPaz düzeylerinde azalma olduğu gözlemlenmiştir. Endosülfanın önemli sitotoksik etkiye sahip olduğu, endosülfana maruz kalan fagositik hücrelerin metabolik aktiviteleri ile migrasyonlarını ve lenfositlerin mitojenik aktivasyonlarını önemli ölçüde baskıladığı bildirilmiştir (Pistl ve ark. 2003). Bir başka çalışmada da $0,001 \mathrm{~g} / \mathrm{ml}(1 \mathrm{ppb})$ endosülfanın insan eritrosit membran yapisinı bozduğu tesbit edilmiş olup, $1 \mathrm{~g} / \mathrm{ml} \quad(1 \mathrm{ppm})$ endosülfan konsantrasyonunda hücrelerin belirgin şekilde zarar gördükleri rapor edilmiştir (Daniel ve ark. 1986).

Endosülfan etkisine maruz birakılan balıklarda da katalaz (CAT) aktivitelerinin endosülfanın düşük dozlarında arttığı, yüksek dozlarında ise azaldığı saptanmıştır (Dorval ve ark. 2003). Glutatyon peroksidaz (GPx) aktivitesi önemli şekilde azalırken, glutatyon transferaz (GST) aktivitesi artmıştır. Adrenokortikal steroidogenik hücrelerin sekretorik cevaplarının azalması dolayısıyla GPx aktivitesi için önemli kofaktör olan glukokortikoid düzeylerinin düştüğü, oksidatif stres yolunda iş gören enzimlerin aktivitelerinin de değiştiği saptanmışır. Yine aynı çalışmada lipit hidroperoksit düzeylerinin yükselmesi, endosülfanla oluşturulan oksidatif stresin bir bulgusu olarak değerlendirilmiştir (Dorval ve ark. 2003).

Vitamin C (VitC), meyve ve sebzelerde doğal olarak üretilen bir antioksidandır. Organik gübrelerle yetiştirilen fakat pestisit kullanılmayan ürünlerde yüksek düzeyde $\mathrm{VitC}$ ölçülmüş ve pestisitten fakir ürünlerin daha fazla antioksidan içerdikleri tesbit edilmiştir. VitC, memeli hayvanlarda bağırsaklardan emilen, canlı vücudunda plazmada ve hücreler içerisinde bulunan primer bir antioksidan olup plazma membranları ile etkileşim halindedir ve $\alpha$ tokoferolün geri dönüşümünü sağlayarak membran lipitlerini peroksidasyondan korur (May 1999). VitC, belirli enzimlerin redükte formda tutulmasını sağlayarak dokuları zararlı oksidatif ürünlerden korumaktadır (Padh 1990).

Subakut endosülfan zehirlenmesi ile ilgili çalışmaların çoğu rat ve fareler üzerine olup, tavşanlarda oral endosülfan alımının etkisi üzerine sinırlı bilgiler mevcuttur. Endosülfanin oral yolla verilmesinin sebebi, tehlikeli bölgelerde yaşayan insanların genellikle endosülfan etkisine bu şekilde maruz kalmasından dolayıdır. Bu çalışmanın amacı, endosülfanın bazı hematolojik ve biyokimyasal parametreler, ve oksidan-antioksidan denge üzerine etkisini ve normal değerlerinden sapan bulguların VitC ile düzeltilebilirliğinin araştırılmasıdır.

\section{MATERYAL ve YÖNTEM}

Akdeniz Üniversitesi Etik Komitesi tarafından onaylanan bu çalşmada (2004.01.0108.001) Pera Tavşan Firmasından (Yeşilyurt-ANTALYA) tedarik edilen 6-8 aylık ve ağırlıkları $2,8-3,7 \mathrm{~kg}$ arasında değişen 24 adet erkek Yeni Zellanda tavşanı kullanıldı. Tavşanlar galvanize kafeslerde bireysel olarak tutuldular ve çalışmaya başlamadan önce 1 ay boyunca laboratuvar şartlarına (10 saat aydınlık 14 saat karanlık ve $24 \pm 5{ }^{\circ} \mathrm{C}$ ) alıştırıldılar. Çalışma süresince tavşanların ağırlıkları haftalık olarak tartıldı ve ağırliklarına göre doz ayarlaması yapıldı.

$\mathrm{Su}$ ve yem ad libitum olarak verildi. Tavşanlar standart ticari tavşan yemi (Burdur Ekinciler yem fabrikasının, $\% 88$ kuru madde, $\% 9$ kül, $\% 16$ ham protein, $\% 15$ ham sellüloz ve $2600 \mathrm{kcal} / \mathrm{kg}$ metabolize olabilir enerji içeren) ile beslendiler.

\section{Çalışma Grupları}

Erkek tavşanlarda, oral subakut endosülfan toksisitesi oluşturmak amaciyla uygulanacak dozun belirlenmesi için, bu araştırmaya başlamadan önce ön denemeler yapildı. Ön denemelerde endosülfanın günlük $1.50 \mathrm{mg} / \mathrm{kg}$ canlı ağırlık oral doz uygulamalarının, endosülfan toksisitesine bağlı olarak, ölüm ile sonuçlandığı gözlemlendi 
(Hatipoglu ve ark, 2008). Bu yüzden en yüksek metabolik etki ve en düşük ölüm oranını elde etmek için endosülfanın oral dozu günlük 1,0 $\mathrm{mg} / \mathrm{kg}$ canlı ağırlık olarak belirlendi. Buna rağmen, araştırmamız sırasında, TRT-II ve IV gruplarından birer tavşanda endosülfan zehirlenmesine bağlı ölüm gözlendi. Çalışmanın ilk 4 haftası alıştırma dönemi, sonraki 6 haftası ise deneysel çalışma dönemi olarak planlandi. Tavşanlar her grupta 6 tavşan olacak şekilde 4 gruba ayrildılar. Gruplardaki çalışma protokolu aşağıdaki gibidir (n $=6)$.

TRT-I: Kontrol grubu: günlük misır yağ1 oral (3 kg canlı ağırlık için $1 \mathrm{~mL}$ mısır yağı);

TRT-II: Endosülfan grubu: günlük endosülfan (1 $\mathrm{mg} / \mathrm{kg}$ canlı ağırlık) misır yağı içerisinde (1 mL misır yağ1 $3 \mathrm{mg}$ endosülfan);

TRT-III: Vitamin C grubu: günlük misır yağı oral (3 kg canlı ağırlık için $1 \mathrm{~mL}$ mısır yağı) + VitC, iki günde bir $(20 \mathrm{mg} / \mathrm{kg}$ canlı ağırlık) çeşme suyu içerisinde ( $1 \mathrm{~mL}$ çeşme suyu $20 \mathrm{mg} \mathrm{VitC)}$ );

TRT-IV: Endosülfan ve Vitamin C grubu: günlük endosülfan (1 mg/kg canlı ağırlık) mısır yağı içinde (1 mL misır yağ1 $3 \mathrm{mg}$ endosülfan $)+\mathrm{VitC}$, iki günde bir $(20 \mathrm{mg} / \mathrm{kg}$ canlı ağırlık) çeşme suyu içerisinde (1 mL çeşme suyu $20 \mathrm{mg} \mathrm{VitC}$ ).

Tavşanlara yaklaşık $3 \mathrm{~kg}$ canlı ağırlık için $1 \mathrm{ml}$ mısır yağ1 verildi. Endosülfan ve VitC'nin dozu haftalık canlı ağırllğa göre ayarlandı. Her tavşan için hesaplanan uygun doz, şırrngaya tespit edilmiş olan plastik gavaj ile özafaringeal bölgeye uygulandı. Denemenin son günü 12 saat aç birakılan tavşanların kulak arterlerinden kan örnekleri alınarak hematolojik ve biyokimyasal analizler için kullanıldı.

\section{Hematolojik ve Biyokimyasal Parametreler}

Hematolojik parametreler (eritrosit sayıs1, hematokrit, lökosit sayısı ve trombositler) tam otomatik hematolojik analiz cihazında (Human Gesellschaft für Biochemica und Diagnostica $\mathrm{GmbH}$, Germany) ölçüldü. Eritrositlerin sedimentasyon hizları rutin Westergren metoduyla 1 saatlik çökme seviyelerinin okunması suretiyle belirlendi (Jou ve ark, 2011). Eritrositlerin frajiliteleri, spektrofotometrik olarak \% $\quad 50$ hemolizin görüldüğü tuz çözeltileri ile saptanarak takip edildi (Bucher 1988). Özetle, içlerinde $\mathrm{NaCl}$ yoğunlukları \% 0,85 ile \%0,30 arasında değiş̧en 12 tüp hazırlandı (toplam hacim $1 \mathrm{ml}$ ). Onüçüncü tüpe ise distile su $(\% 0,0 \mathrm{NaCl})$ ilave edildi. Her tüpe 0,1 $\mathrm{ml}$ kan eklendi. İçerik hafifçe karıștırıldı. Tüpler 2627 'C'de 20 dakika bekletildikten sonra 1500 g'de 20 dakika santrifüj edildi. Tüplerdeki süpernatantlar küvete aktarıldı. Spektrofotometre aracilğ̆yla küvetteki hemoglobin miktar1 540 nm'de okundu. Hemoliz yüzdesi test tüpünden elde edilen okumanın $\% 0,0^{\prime} l 1 k \mathrm{NaCl}$ tüpündeki okumasına bölünerek ve daha sonra 100 ile çarpilarak hesaplandı (Shimadzu Recording Spectrophotometer UV-1601, Japan). Plazma C vitamini fosfotungstat metodu ile spektrofotometrik olarak ölçüldü. Deneyin prensibi askorbik asidin alkali ortamda fosfotungustik asit ile okside edilmesi ve fosfotungustik asidi indirgemesi sonucu mavi rengin oluşumu esasına dayanır. Meydana gelen mavi renkli çözelti daha sonra spektrofotometre aracilığıly $690 \mathrm{~nm}$ dalga boyunda absorbans1 ölçüldü (Kyaw 1978).

Plazma glukozu, primer aromatik bir amin olan otoluidin'in sıcak glasiyal asetik asit içinde glukozun terminal aldehit grubuyla mavi-yeşil bir renk oluşturmak üzere reaksiyona girmesi prensibine dayalı o-toluidin metoduna göre (Feteris, 1965) belirlendi. Eritrosit CAT aktivitesi; Aebi'nin (1984) tanımladığı metoda göre kısaca serumun, hidrojen peroksit içeren fosfat tamponuyla $(30 \mathrm{mM}, \mathrm{pH} 7.0)$ reaksiyonu sonucu $240 \mathrm{~nm}$ 'deki absorbansindaki azalmanın ölçülmesiyle belirlendi. GPx, Beutler'in (1975) metoduna göre ölçüldü. Bu metoda göre, redükte glutatyon (GSH) t-butil hidroperoksit varlığında GPx aktivitesiyle okside glutatyona (GSSG) dönüşür ve GSSG glutatyon redüktaz (GR) ve NADPH yardımıla tekrar GSH'ye indirgenir ve $\mathrm{NADP}^{+}$meydana gelir. GPx aktivitesi, NADPH'in NADP+'ye yükseltgenmesi sırasındaki absorbans farkinın 340 nm'de okunmasiyla belirlenir. Plazma Malondialdehid (MDA) düzeyi, MDA ile tiyobarbitürik asit (TBA) arasındaki reaksiyona dayalı spektrofotometrik metotla (Satoh, 1978) ve G6PD enzim aktivitesindeki değişimler, spektrofotometrede 37 ${ }^{\circ} \mathrm{C}$ 'ta Beutler'in (1983) metoduna göre tespit edildi. Bu metod, substrat glukoz 6-fosfat ve kofaktör NADP'nin G6PD tarafindan NADPH'a indirgenmesi esasına dayanır. G6PD aktivitesine bağlı olarak artan NADPH'ın 340 nm'deki absorbans değişimi ölçüldü. Enzim aktivitesi, IU.gHb ${ }^{-1} \cdot \mathrm{dak}^{-1}\left(37^{\circ} \mathrm{C}, \mathrm{pH}\right.$ 8.0) olarak açıklandı (IU: $37^{\circ} \mathrm{C}$ 'de dakikada $1 \mathrm{mmol} \mathrm{NADP}^{+}$yi indirgeyen enzim miktarıdır). Diğer biyokimyasal parametreler (ALT, AST ve ALP) ise otoanalizör (Roche Modular PP otoanalizör, Roche Diagnostics, Mannheim, Germany) ile ölçüldü.

\section{İstatistiksel Analiz}

Bütün değerler ortalama değerler olarak verildi. İstatistiksel değerlendirme için SAS (PROC GLM prosedürü) istatistik programından faydalanıldı. Gruplar arası farklılı̆̆ karşılaştırmak için "Dunnett post hoc" analizi yapıldı. Gruplar arası farklılık $\mathrm{P}<$ 0,05 olduğunda önemli olarak kabul edildi. 


\section{BULGULAR}

TRT-II ve TRT-IV gruplarından birer tavşan, tipik endosülfan toksisitesi (hipereksitabilite, dispne, hiperpne, tremor ve tonik-klonik konvulsionlar, kafes duvarlarına çarpma, depresyon, göğüs üzerine yatarak ön ayakların ekstensiyonu) göstererek öldüğü için çalışmadan çıkarıldı. Kontrol ve çalışma grupları arasında ise canlı ağırlık bakımından farklılık görülmedi (Tablo 1).

Hematolojik parametreler arasında sadece lökosit sayısının ve eritrosit sedimentasyon hizının (ESR), biyokimyasal parametrelerden ise VitC, ALP ve AST değerlerinin etkilendiği görülmektedir (Tablo 1 ve 2). Lipit peroksidasyon belirteci olan serum MDA düzeyi ve serum G6PD, GPx enzim aktiviteleri ile eritrosit CAT aktivitesi de gruplar arasında istatistiksel olarak farklı bulunamamıştır (Tablo 2). Benzer bir şekilde, eritrosit sayısında, hemoglobin ve hematokrit değerlerinde, lenfosit, granülosit, monosit yüzde oranlarında ve trombosit sayısında önemli bir değişiklik gözlemlenmemiştir (Tablo 1).

Lökosit değerleri TRT-I, TRT-II ve TRT-III gruplarında birbirlerinden farklı değilken, TRT-IV grubunda bulunan tavşanlarda lökosit değerleri TRT-I ve II gruplarına göre bir düşüş göstermiştir. Eritrosit sedimentasyon hızının endosülfanın etkisi ile arttığ1 (TRT-II), TRT-IV grubundaki tavşanlarda ise VitC ilavesinin sedimentasyon hızını TRT-I grubundaki seviyelere düşürdügü müşahade edilmiştir (Tablo 1).

TRT-III grubunda ise lökosit değerlerinde bir azalma gözlenmiş olmakla birlikte, bu azalma kontrol grubuna göre önemli bulunmamıştır. VitC uygulamasının, lökositlerin sayısındaki bu düşüşe engel olamadı̆̆1 görülmektedir (Tablo 1). Serum VitC düzeyinde ise, TRT-IV grubunda, TRT-I ve II gruplarına göre fark gözlenmezken, TRT-III grubuyla karşılaştıılldı̆̆ında azalma saptanmıştır. TRT-II grubundaki serum VitC düzeyleri, TRT-I ve III gruplarına göre önemli ölçüde azalırken, TRT-III grubunda diğer gruplardan daha yüksek serum VitC düzeyi tespit edilmiştir (Tablo 2).

Serum glukoz düzeyleri TRT-II grubunda TRT-I grubuna göre yükselmiş olmasına rağmen, bu yükselme istatistiksel önemde bulunmamıştır. TRTIII grubunda ise serum glukoz düzeylerinde bir düşüş gözlenmiş ancak bu düşüş de TRT-I grubuna göre önemli bulunmamıstır (Tablo 2).

Serum ALT enzim aktivitesinde, gruplar arasindan herhangi bir fark gözlenmemiştir. Fakat, TRT-II grubunda serum ALP ve AST seviyelerinde diğer gruplara göre istatistiksel olarak önemli bir artış belirlenmiştir. Endosülfan ile birlikte yapılan VitC uygulamasinin ise ALP ve AST seviyelerini TRT-I grubu düzeylerine düşürdüğü gözlenmiştir (Tablo 2).

TRT-I, II ve IV gruplarında $\% \quad 0,55 \quad \mathrm{NaCl}$ konsantrasyonunda eritrositlerin \% 50'sinin dayanıksız olduğu tesbit edilirken, VitC uygulanan grupta osmotik frajilite oranının aynı tuz konsantrasyonunda $\% \quad 40$ 'da kaldığ1 görüldü. Eritrositlerin \%70-80'i, \%0,50’lik $\mathrm{NaCl}$ konsantrasyonunda hemoliz olurken, VitC uygulanan grupta bu oranın \%60'ta kaldığ1 gözlendi. Gruplar arasında istatistiksel bir önem olmamasına karşın, VitC uygulanan grupta eritrositlerin diğer gruplara nazaran daha dayanıklı olduğu gözlemlendi.

Tablo 1. Endosülfan ve C vitamini uygulanan erkek Yeni Zellanda Tavşanlarında vücut ağırlıkları ve hematolojik parametreler.

Table 1. Final body weights and hematological parameters of male New Zealand White rabbits treated with endosulfan and Vitamin C

\begin{tabular}{lccccc}
\hline & $\begin{array}{c}\text { TRT-I } \\
(\mathrm{n}=6)\end{array}$ & $\begin{array}{c}\text { TRT-II } \\
(\mathrm{n}=5)\end{array}$ & $\begin{array}{c}\text { TRT-III } \\
(\mathrm{n}=6)\end{array}$ & $\begin{array}{c}\text { TRT-IV } \\
(\mathrm{n}=5)\end{array}$ & P< \\
\hline Canlı ağirlık $(\mathrm{g})$ & $3031,9 \pm 142,6$ & $3156,7 \pm 156,2$ & $3162,4 \pm 141,6$ & $2980,7 \pm 154,2$ & $\mathrm{NS}$ \\
Eritrosit $\left(\mathrm{x} 10^{6} / \mu \mathrm{l}\right)$ & $6,99 \pm 0,19$ & $6,91 \pm 0,23$ & $6,60 \pm 0,20$ & $6,63 \pm 0,24$ & $\mathrm{NS}$ \\
Hb $(\mathrm{g} \%)$ & $13,45 \pm 0,81$ & $12,76 \pm 0,46$ & $13,07 \pm 0,39$ & $13,56 \pm 0,45$ & $\mathrm{NS}$ \\
Htc $(\%)$ & $40,65 \pm 0,81$ & $38,00 \pm 0,96$ & $37,39 \pm 0,82$ & $38,96 \pm 0,96$ & $\mathrm{NS}$ \\
Lökosit $\left(\mathrm{x} 10^{3} / \mu \mathrm{l}\right)$ & $9,13 \pm 0,58^{\mathrm{a}}$ & $8,41 \pm 0,69^{\mathrm{a}}$ & $7,91 \pm 0,59 \mathrm{ab}$ & $6,27 \pm 0,70^{\mathrm{b}}$ & 0,04 \\
Lenfosit $(\%)$ & $39,97 \pm 2,41$ & $37,82 \pm 2,85$ & $35,82 \pm 2,42$ & $41,20 \pm 2,86$ & $\mathrm{NS}$ \\
Granulosit $(\%)$ & $52,46 \pm 2,78$ & $49,26 \pm 3,31$ & $52,59 \pm 2,80$ & $45,90 \pm 3,30$ & $\mathrm{NS}$ \\
Monosit $(\%)$ & $11,49 \pm 0,86$ & $12,88 \pm 0,98$ & $11,57 \pm 0,86$ & $12,68 \pm 1,02$ & $\mathrm{NS}$ \\
Trombosit $\left(\mathrm{x} 10^{3} / \mu \mathrm{l}\right)$ & $480,8 \pm 34,5$ & $471,5 \pm 35,3$ & $438,5 \pm 34,6$ & $407,3 \pm 40,9$ & $\mathrm{NS}$ \\
ESR (mm/saat) & $2,5 \pm 0,82^{\mathrm{ab}}$ & $4,33 \pm 0,89^{\mathrm{a}}$ & $1,14 \pm 0,83^{\mathrm{b}}$ & $2,99 \pm 1,05^{\mathrm{ab}}$ & 0,05 \\
\hline
\end{tabular}

Aynı satırda farklı harfleri taşıyan değerler arasında istatistiksel farklılık vardır $(\mathrm{p}<0,05)$. NS $=\mathrm{p}>0,1$.

TRT-I $=$ Kontrol, TRT-II $=1 \mathrm{mg} / \mathrm{kg}$ endosülfan, TRT-III $=20 \mathrm{mg} / \mathrm{kg}$ vitamin $\mathrm{C}$, TRT-IV $=1 \mathrm{mg} / \mathrm{kg}$ endosülfan +20 $\mathrm{mg} / \mathrm{kg}$ vitamin $\mathrm{C}$; ESR=Eritrosit sedimentasyon hızı. 
Tablo 2. Endosülfan ve C vitamini uygulanan erkek Yeni Zellanda Tavşanlarında kan antioksidan enzimleri ve biyokimyasal parametreler.

Table 2. Blood antioxidant enzymes and biochemical parameters of male New Zealand White rabbits treated with endosulfan and Vitamin C.

\begin{tabular}{lccccc}
\hline & $\begin{array}{c}\text { TRT-I } \\
(\mathrm{n}=6)\end{array}$ & $\begin{array}{c}\text { TRT-II } \\
(\mathrm{n}=5)\end{array}$ & $\begin{array}{c}\text { TRT-III } \\
(\mathrm{n}=6)\end{array}$ & $\begin{array}{c}\text { TRT-IV } \\
(\mathrm{n}=5)\end{array}$ & P< \\
\hline Glukoz $(\mathrm{mg} / \mathrm{dl})$ & $139,9 \pm 7,69$ & $148,6 \pm 7,79$ & $121,8 \pm 7,37$ & $128,2 \pm 8,56$ & $\mathrm{NS}$ \\
Vitamin C (mg/dl) & $1,60 \pm 0,04^{\mathrm{a}}$ & $1,43 \pm 0,05^{\mathrm{b}}$ & $1,72 \pm, 0,04^{\mathrm{c}}$ & $1,53 \pm 0,06^{\mathrm{ab}}$ & 0,01 \\
MDA (nmol /ml) & $1,73 \pm 0,14$ & $1,51 \pm 0,14$ & $1,77 \pm 0,12$ & $1,44 \pm 0,15$ & $\mathrm{NS}$ \\
G6PD (U/gHb) & $3,78 \pm 0,48$ & $3,61 \pm 0,61$ & $3,90 \pm 0,47$ & $4,88 \pm 0,56$ & $\mathrm{NS}$ \\
GPX(U/gHb) & $11,23 \pm 0,74$ & $12,23 \pm 0,83$ & $12,07 \pm 0,79$ & $12,95 \pm 0,92$ & $\mathrm{NS}$ \\
ErKat (U/gHb) & $23,17 \pm 1,24$ & $24,13 \pm 1,29$ & $25,99 \pm 1,15$ & $22,97 \pm 1,43$ & $\mathrm{NS}$ \\
ALP (IU/l) & $71,2 \pm 9,9 \mathrm{a}$ & $131,5 \pm 13,4 \mathrm{~b}$ & $70,7 \pm 11,5^{\mathrm{a}}$ & $86,9 \pm 15,8 \mathrm{a}$ & 0,02 \\
AST(IU/l) & $26,7 \pm 4,1^{\mathrm{a}}$ & $41,3 \pm 5,3 \mathrm{~b}$ & $23,6 \pm 3,8^{\mathrm{a}}$ & $30,4 \pm 4,9 \mathrm{a}$ & 0,03 \\
ALT(IU/l) & $41,6 \pm 4,3$ & $47,0 \pm 5,6$ & $46,5 \pm 1,15$ & $49,5 \pm 5,8$ & $\mathrm{NS}$ \\
\hline
\end{tabular}

Aynı satırda farklı harfleri taşıyan değerler arasında istatistiksel farklılık vardır $(\mathrm{p}<0,05)$. NS=p $>0,1$.

TRT-I= Kontrol, TRT-II $=1 \mathrm{mg} / \mathrm{kg}$ endosülfan, TRT-III $=20 \mathrm{mg} / \mathrm{kg}$ vitamin C, TRT-IV= $1 \mathrm{mg} / \mathrm{kg}$ endosülfan +20 $\mathrm{mg} / \mathrm{kg}$ vitamin C; MDA= Malonil dialdehid, G6PD= Glukoz 6 Fosfat Dehidrojenaz, GPX= Glutatyon peroksidaz, ErKat $=$ Eritrosit Katalaz

\section{TARTIŞMA}

Endosülfan, Türkiye dahil bir çok ülkede tarımsal mücadelede kullanılan güçlü bir insektisittir. Dünya Sağlık Örğütü, endosülfanı orta şiddette zehirli olarak sinıflandırmasına rağmen, akut ölüm oluşturacak kadar şiddetli zehirlenmeye de sebep olabilmektedir (Xu ve ark. 2017).

Çalısmamızda, hematolojik parametreler arasında sadece lökosit sayısının etkilendiği görülmektedir. Lökosit değerleri TRT-I, II ve III gruplarında birbirlerinden farklı değilken, VitC'nin ES ile birlikte verildiği TRT-IV grubunda diğerlerinden farklı olmak üzere bir düşüş olmuştur. Endosülfan total lökosit sayısında azalmaya neden olmakla birlikte, sadece TRT-IV grubunda diğerlerine göre istatistiksel önem arz etmektedir. Çalışmamızda kullanmış olduğumuz VitC dozunun lökositlerin sayısındaki bu düşüşe engel olamadığ1 görülmektedir. Kanatlllarda yapılan bir çalışmada günlük $30 \mathrm{ppm}$ dozunda verilen endosülfanın beyaz kan hücreleri üzerine etkili olmadığ1 bildirilmiştir (Singh ve ark. 2016). Ratların kullanıldığı farklı bir çalışmada günlük ortalama alım dozunun 100 katı kadar olan $(0,6 \mathrm{mg} / \mathrm{kg})$ endosülfan uygulamalarında hiçbir parametrede değişiklik oluşmazken, doz $1000(6,12 \mathrm{mg} / \mathrm{kg})$ katına çıkarıldığında lökosit sayısında bir düşüşün olduğu bildirilmiştir (Akay ve ark. 1999). Endosülfanın bu etkisinin lökosit göçünü inhibe ederek, lökosit apoptozisini uyararak veya lökositler üzerindeki olası mutajenik ve genotoksik etkileri sebebiyle olabileceği belirtilmiştir (Akay ve ark. 1999; Kannan ve ark. 2000).
ESR, akut faz yanıtını değerlendirmede kullanılan parametrelerden biridir. Akut faz yanıtı ise doku hasarı varlığının belirlenmesi için kullanılabilecek iyi bir veridir. Doku hasarı geliştiğinde özellikle serum fibrinojen, serum amiloid A proteini ve C-reaktif protein miktar1 artar (Gabay ve Kushner 1999). Ayrıca, serum karaciğer enzim seviyelerindeki azalmanın ESR'yi azalttı̆̆g, artışın ise ESR'de artışa sebep olduğu bildirilmiştir (Targer ve ark, 2008). Endosülfanın farklı dozlarda uygulandığı önceki çalışmamızda, tavşanlarda özellikle karaciğer ve böbreklerde doku hasarına yol açttğı gözlenmiştir (Hatipoglu ve ark, 2008). Ayrıca, çalışmamızdaki karaciğer enzimlerindeki artış da bu hasarı desteklemektedir. Çalısmamızda ESR değerleri TRT-II grubundaki tavşanlarda TRT-III grubundakilere göre yükselmesine rağmen, endosülfanla birlikte VitC verilen grupta (TRT-IV) ESR değerlerindeki artışın engellendiği gözlenmektedir. $\mathrm{Bu}$ durum, karaciğer enzimlerindeki değişime paralel olarak, VitC'nin endosülfanın oluşturduğu doku hasarı üzerine düzeltici etkisi olduğunu düşündürmektedir.

Daha önceki araştırmalarda da gözlendiği gibi (Naqvi ve Vaishnavi 1993; Narra ve ark. 2015; Kumar ve ark 2016) serum glukoz düzeyleri TRTII grubunda TRT-I grubuna göre yükselmiş olmasina rağmen, bu yükselme istatistiksel önemde bulunmamıştır. TRT-III grubunda ise glukoz seviyelerinde düşme gözlenmiş, ancak bu da TRT-I grubuna göre önemli bulunmamıştır. Endosülfan uygulamalarıyla, muhtemelen karaciğer hasarına ve strese bağli olarak meydana gelebilecek serum glukoz artışının, VitC uygulamaları ile düzeltilebileceği daha önce de bildirilmiştir (Narra ve ark. 2015). VitC uygulamalarının, antioksidan özelliğiyle karaciğer hasarını önleyici olabileceği ve 
stresi azaltarak glikojen y1k1mlanmasındaki olas1 artış1 engelleyebileceği düşünülmektedir (Narra ve ark. 2015).

VitC düzeyi ise, TRT-IV grubunda TRT-I grubuna göre fark göstermezken, TRT-II grubunda önemli şekilde düşmüş, TRT-III grubunda ise muhtemelen VitC yüklemesine bağlı olarak yükselmiştir. Ancak, lökosit seviyelerinde gözlendiği gibi, TRT-IV grubundaki tavşanların serum $\mathrm{ViC}$ seviyelerindeki düşüşün, sadece VitC uygulanan TRT-III grubuyla kıyaslandığında, engellenemediği gözlenmiştir.

Çalışma gruplarındaki tavşanların canlı ağırlıklarında, eritrosit sayısında, hemoglobin, hematokrit, lenfosit, granülosit, monosit ve trombosit değerlerinde önemli bir değişiklik gözlemlenmemiştir. Tür farklılı̆̆1 olmakla birlikte, Pal ve arkadaşlarının (2004) broyler tavuklarda yapmış olduğu çalışmasında da benzer sonuçlar bildirilmiştir. Uygulanan endosülfan dozunun hematolojik parametreler üzerine, deneme süresi içerisinde etkisinin çok sınırlı kaldığı saptanmıştır.

Endosülfan toksikasyonundan en fazla etkilenen organlar karaciğer ve böbreklerdir (BlancoCoronado ve ark. 1992; Segasothy ve Pang 1992). Endosülfanın atılımı dişkı ve idrarla olduğundan birikim en fazla bu organlarda şekillenir. Serum ALT, AST ve ALP, karaciğer fonksiyonları hakkında bilgi veren önemli enzimlerdir. Karaciğer dokusunda bir dejenerasyon olduğunda, bu enzimlerin serum seviyelerinde bir artış gözlenmektedir (Henderson ve Moss 2005). Çalışmamızda endosülfan uygulamalarının erkek tavşanlarda ALP ve AST enzimlerinin serum seviyelerini artırdığı sonucuna varılmıştır. Daha önce yaptığımı çalışmada gözlemlediğimiz karaciğer dokusundaki hasar da bu bulguları desteklemektedir (Hatipoglu ve ark. 2008). Farelerde yapılan benzer bir çalışmada da endosülfanın karaciğer enzimlerini yükselttiği belirtilmiştir (Mansour ve ark. 2017). Bu enzimlerin yükselme derecesi hepatoselüler fonksiyon kaybı ile doğru orantılıdır. Endosülfanın oksidatif stresi artırdığ1 ve organlarda toksisiteye sebep olabileceği konusunda çalışmalar mevcuttur (Korkmaz ve ark. 2010; Daidoji ve ark. 2003). Bu durumun reaktif oksijen ürünlerinde ve serbest radikal seviyelerinde artışa sebep olarak, prooksidan ve antioksidan dengesini bozduğu ve karaciğer dokusunda harabiyete sebep olduğu ileri sürülmüştür (Videla 2009). Endosülfanın VitC ile beraber verildiği TRT-IV grubunda ise bu enzim seviyelerinin yükselmediği, bilakis kontrol düzeylerinde kaldığ1 gözlenmiştir. Kuvvetli bir antioksidan olan VitC bu etkisini reaktif oksijen türlerini (ROS) sistemden uzaklaştırarak, lipid peroksidasyonunu baskılayarak veya dolayli yoldan antioksidan savunma sistemini koruyarak göstermiş olabilir.
Etki mekanizması ile ilgili in vitro çalışmalar; endosülfanın oksidatif fosforilasyona karışmadığını (Kannan ve Jain 2003), endojen antioksidanların ve karaciğer superoxide dismutaz (SOD) aktivitesinde azalma meydana getirdiğini (Bebe ve Panemangalore 2003), ve ROS'un ve dolayisiyla ortaya ç1kan oksidatif stresin (Sohn ve ark. 2004) dokularda hasara yol açtığını (Rao ve ark. 2005) göstermiştir. Vitamin C'nin iyileştirici etkisi, pek çok metabolik yolda ortaya çıkan toksik etkili serbest oksijen radikallerini yakalamasına ve güçlü bir antioksidan olmasina atfedilmektedir (Dawson ve ark. 1992).

\section{SONUÇ}

Çalışmamızda uygulanan endosülfan dozlarının (1 mg/kg canlı ağırlık, oral doz) hematolojik parametreler üzerine etkisinin sinırlı kaldığı gözlemlenmiştir. Endosülfan etkisiyle ortaya çıkan lökosit sayısındaki azalmanın, VitC uygulamaları ile engellenemediği görülmektedir. Ayrıca, uygulanan endosülfan dozunda, antioksidan enzim aktivitelerinde ve lipit peroksidasyon (MDA) düzeylerinde de önemli bir değişiklik gözlenememiştir. Buna rağmen, endosülfan toksikasyonunda karaciğer enzimlerinde (ALP ve AST) artış görülmüş ve Vit C'nin bu artışı normal seviyelerine düşürdüğü belirlenmiştir. Sonuç olarak, tavşanlarda subakut endosülfan toksikasyonunun, karaciğer enzimlerindeki düşüş göz önüne alındığında, VitC'nin hücre koruyucu özelliği dolayısı ile endosülfan intoksikasyonunda yararlı olabileceği sonucuna varılmıştır.

\section{TEŞEKKÜR}

Yardımlarından dolayı Sayın Mehmet Uğur Özceylan’a, Sayın Bedri Başakın’a ve Data Medikale teşekkür ederiz.

\section{KAYNAKLAR}

Aebi H. Catalase in vitro. Methods Enzymol. 1984; 105: 121-126.

Akay MT, Ozmen G, Elcuman EA. Effects of combinations of endosulfan, dimethoate and carbaryl on immune and hematological parameters of rats. Vet Hum Toxicol. 1999; 41(5):296-9.

Bebe FN, Panemangalore M. Exposure to low doses of endosulfan and chlorpyrifos modifies endogenous antioxidants in tissues of rats. J Environ Sci Health B. 2003; 38: 349-363.

Beutler E. Glucose-6 Phosphate Dehydrogenase Deficiency. In: The Metabolic Bases of the Inheredited. Disease, Ed; Mc Graw-Hill 
Education - Europe, 8th Ed., Mc Graw-Hill Medical, New York, USA. 1983; pp. 16291653.

Beutler E. Red Cell Metabolism. In: A Manual of Biochemical Methods, Grune and Straton, New York, USA. 1975; pp.67-69.

Blanco-Coronado JL, Repetto M, Ginestal RJ, Vicente JR, Yelamos F, Lardelli A. Acute intoxication by endosulfan. J Toxicol Clin Toxicol. 1992; 30(4): 575-583.

Bremer JN, Leist KH. Endosulfan (AE F002671, substance technical). Valuation of the acute oral and dermal toxicity. Hoechst document A59823, Frankfurt, Germany, 1998.

Bucher U. Labormethoden in der Haematologie. Verlag Hans Huber, Bern. 1988.

Daidoji $\mathbf{T}$, Inoue $\mathbf{H}$, Kat $\mathrm{S}$, Yokota $\mathbf{H}$. Glucuronidation and excretion of nonylphenol in perfused rat liver. Drug Metabolism Disposal. 2003; 31: $993-$ 998.

Daniel CS, Agarwal S, Agarwall SS. Human red blood cell membrane damage by endosulfan. Toxicol Lett. 1986; 32 (1-2), 113-118.

Dawson EB, Harris WA, Powell LC. Relationship between ascorbic acid and male fertility. World Rev Nutr Diet. 1990; 62: 126.

Dawson EB, Harris WA, Teter MC, Powell LC. Effect of ascorbic acid supplementation on the sperm quality of smokers. Fertil Steril. 1992; 58: 1034-1039.

Dorval J, Leblond VS, Hontela A. Oxidative stress and loss of cortisol secretion in adrenocortical cells of rainbow trout (Oncorynchus mykiss) exposed in vitro to endosulfan, an organochlorin pesticide. Aquat Toxicol. 2003; 63(3): 229-241.

Feteris WA. A serum glucose method without protein precipitation. Am J Med Technol. 1965; 31: 17-21.

Gabay C, Kushner I. Acute-phase proteins and other systemic responses to inflamation. New England J Med. 1999; 340:448-454.

Hatipoglu FS, Gulay MS, Balic A, Yildiz-Gulay O, Volkan S. Subacute Oral Toxicity of Endosulfan in Male New Zealand White Rabbits. Toxicol Mechanisms Methods. 2008; 18: 705-710.

Henderson AR, Moss DW. Tietz fundamentals of clinical chemistry. Ed; Burtis CA, Ashwood ER, Lubbok, Texas, USA. 2005; 352-392.
Jou J, Lewis S, Briggs C, Lee S, De La Salle B, McFadden S. ICSH review of the measurement of the erythocyte sedimentation rate. Int J Lab Hematol. 2011; , 33, 125-132.

Kannan K., Holcombe RF, Jain SK, AlvarezHernandez $X$, Chervenak R, Wolf RE, Glass J. Evidence for the induction of apoptosis by endosulfan in a human T-cell leukemic line. Mol Cell Biochem. 2000; 205: 53-66.

Kannan K, Jain SK. Oxygen radical generation and endosulfan toxicity in Jurkat T-cells. Mol Cell Biochem. 2003; 247: 1-7.

Korkmaz A, Ahbab MA, Kolankaya D, Barlas N. Influence of vitamin $C$ on bisphenol $A$, nonylphenol and octylphenol induced oxidative damages in liver of male rats. Food Chem Toxicol. 2010; 48(10): 2865-2871.

Kumar N, Ambasankar K, Krishnani KK, Gupta SK, Bhushan S, Minhas SP. Acute toxicity, biochemical and histopathological responses of endosulfan in Chanos chanos. Ecotoxicol Environ Safety. 2016; 131: 79-88.

Kyaw A. A simple colorimetric method for ascorbic acid determination in blood plasma. Clinica Chimica Acta. 1978; 86(2):153-157

Mansour S, Abdel-Mageed M, Mohamed K, Gad M, Gamet-Payrastre L. Adverse Effects to Suckling Mice Following Indirect Exposure to a Pesticide Mixture and Ameliorative Effect of $\alpha$-Tocopherol Coadministration. J Basic Clin Health Sci. 2017; 3: 71-78.

May MJ. Is ascorbic acid an antioxidant for the plasma membrane? FASEB J. 1999; 13: 9951006.

Menezes RG, Qadir TB, Moin A, Fatima H, Hussain SA, Madadin M, Pasha SB, Al Rubaish FA, Senthilkumaran S. Endosulfan poisoning: An overviewEndosulfan poisoning: An overview. J Foren Legal Med. 2017; 51: $27-$ 33.

Naqvi SM, Vaishnavi C. Bioaccumulativ potential and toxicity of endosulfan insecticide to nontarget animals Comp Biochem Physiol C. 1993; 105(3):347-361.

Narra MR, Rajender K, Reddy RR, Rao JV, Begum G. The role of vitamin $C$ as antioxidant in protection of biochemical and haematological stress induced by chlorpyrifos in freshwater fish Clarias batrachus. Chemosphere. 2015; 132: 172 178. 
Padh H. Cellular functions of ascorbic acid. Biochem Cell Biol. 1990; 68: 1166-1173.

Pal AK, Jadhao SB, Garg UK, Jha GJ. Haemato-biochemical ve immunopathophysiological effects of chronic toxicity with synthetic pyrethroid, organophosphate and chlorinated pesticides in broiler chicks. Int Immunopharm. 2004; 13(4): 1709-1722.

Pistl J, Kovalkovicova N, Holovska VV, Legath J, Mikula I. Determination of the immunotoxic potential of pesticides on functional activity of sheep leukocytes in vitro. Toxicology. 2003; 188 (1):73-81.

Rao M, Narayana K, Benjamin S, Bairy KL. LAscorbic acid ameliorates postnatal endosulfan induced testicular damage in rats. Indian J Physiol Parmacol. 2005; 49: 331336.

Satoh K. Serum lipid peroxide in cerebrovascular disorders determined by a new colorimetric method. Clin Chim Acta. 1978; 90: 37-43.

Segasothy M, Pang KS. Acute interstitial nephritis due to endosulfan. Nephron. 1992; 62: 118.

Sharma S, Dewan A, Singh G. Toxico-vigilance: an inevitable prerequisite to keep a watch on toxins around you. J Forensic Leg Med. 2017; 45: 32-35.

Simonich SL, Hites RA. Global distribution of persistent organochlorine compounds. Science. 1995; 29:1851-1854.

Singh PP, Kumar A, Chauhan RS, Pankaj PK. Effect of endosulfan on immunological competence of layer birds. Veterinary World. 2016; 9: 777-782.

Sohn H, Kwon C, Kwon G, Lee J, Kim E. Induction of oxidative stress by endosulfan and protective effect of lipid-soluble antioxidants against endosulfan induced oxidative damage. Toxicol Lett. 2004; 151: 357-365.

Targher G, Bertolini L, Rodella S, Lippi G, Franchini M, Zoppini G, Muggeo $M$, Day CP. NASH Predicts Plasma Inflammatory Biomarkers Independently of Visceral Fat in Men. Obesity. 2008; 16(6):1394-1399.

Xu D, Li S, Lin L, Qi F, Hang X, Sun Y. Gene expression profiling to identify the toxicities and potentially relevant disease outcomes due to endosulfan exposure. Toxicol Res. 2016; 5: 621-632.

Xu D, Liu T, Lin L, Li S, Hang X, Sun Y. Exposure to endosulfan increases endothelial permeability by transcellular and paracellular pathways in relation to cardiovascular diseases. Environ Pollut. 2017; 223: 111-119.

Videla LA. Oxidative stress signaling underlying liver disease and hepatoprotective mechanisms. World J Hepatology. 2009; 1: 72-78.

Zhang P, Zhu W, Wang D, Yan J, Wang Y, Zhou Z, He L. A combined NMR- and HPLC-MS/MS-based metabolomics to evaluate the metabolic perturbations and subacute toxic effects of endosulfan on mice. Environ Sci Pollut Res. 2017; 24: 18870-18880. 